\title{
Creation of a Field Guide to Camas Prairie Plants with Undergraduates: Project-Based Learning Combined with Epistemological Decolonization
}

\author{
Frederica Bowcutt ${ }^{1^{*}}$ \\ ${ }^{1}$ Environmental Studies, The Evergreen State College, Olympia, USA. \\ "bowcutt@@evergreen.edu
}

\begin{abstract}
Remnant camas prairies and associated oak woodlands are the focus of contemporary Indigenous food sovereignty efforts in the Salish Sea (aka Puget Sound) region of western Washington. They are also the focus of research and restoration to conserve at-risk species of animals and plants protected under the United States Endangered Species Act. Currently there is little collaboration between tribes and restoration scientists. These conditions create an opportunity and ethical imperative for developing undergraduate curriculum that highlights the connections between biodiversity conservation and traditional Indigenous ecological knowledge. Patchy mosaic prairie-oak woodland vegetation visibly reflects the imprint of human activity, which includes past burning to foster native food plants including common camas (Camassia quamash) and Oregon white oak (Quercus garryana). Using a floristic research project focused on these cultural landscapes as a case study, this essay illustrates how interdisciplinary inquiry and service learning can enrich college-level plant taxonomy curriculum, while creating rich opportunities for students to link their botanical studies to a historicallygrounded understanding of why the conservation challenges exist in the first place. Through this collaborative, multi-year research effort, students contribute to the production of needed resources useful to regional conservation efforts. Affiliated learning communities also consider what it might mean to decolonize botanical knowledge in the context of ecological restoration.
\end{abstract}

Received August 8, 2020

OPEN ӘACCESS

Accepted December 16, 2020

Published February 12, 2021

DOI 10.14237/ebl.12.1.2021.1723

Keywords Cultural landscapes, Decolonizing pedagogical praxis, Historical ecology, Interdisciplinary learning, Undergraduate floristic research

Copyright (c) 2021 by the author(s); licensee Society of Ethnobiology. This is an open-access article distributed under the terms of the Creative Commons Attribution-NonCommercial 4.0 International Public License (https://creativecommons.org/licenses/by-nc/4.0), which permits non-commercial use, distribution, and reproduction in any medium, provided the original author and source are credited.

\section{Introduction}

This essay examines how the creation of herbariumbased online resources and a field guide with undergraduates can support a more holistic way of teaching floristic research methods, historical ecology, and ecological restoration. Project-based learning, such as this, involves "a systematic teaching method that engages students in learning knowledge and skills through an extended inquiry process structured around complex, authentic questions and carefully designed projects and tasks" (Markham et al. 2003:4). In ethnobiology courses, students gain skills in multiple disciplines, which can include plant taxonomy and botanical illustration. They often also engage complex conservation questions such as: how can cultural landscapes ${ }^{1}$ like camas prairies be restored both technically and ethically? How is the legacy of colonization linked to the need for habitat restoration? And how might structural racism impact contemporary conservation efforts? This case study provides a model for linking interdisciplinary instruction with project-based learning.

In 2016, The Evergreen State College Press published the first edition of $V$ ascular Plants of the South Sound Prairies (Figure 1), a much-needed reference for plant identification that serves both the public and professionals involved in camas (Camassia quamash) prairie and Oregon white oak (Quercus garryana) woodland conservation in the south Puget Sound region (Bowcutt and Hamman 2016). This vegetation mosaic is the focus of ongoing ecological restoration in multiple places within the Willamette Valley/Puget 


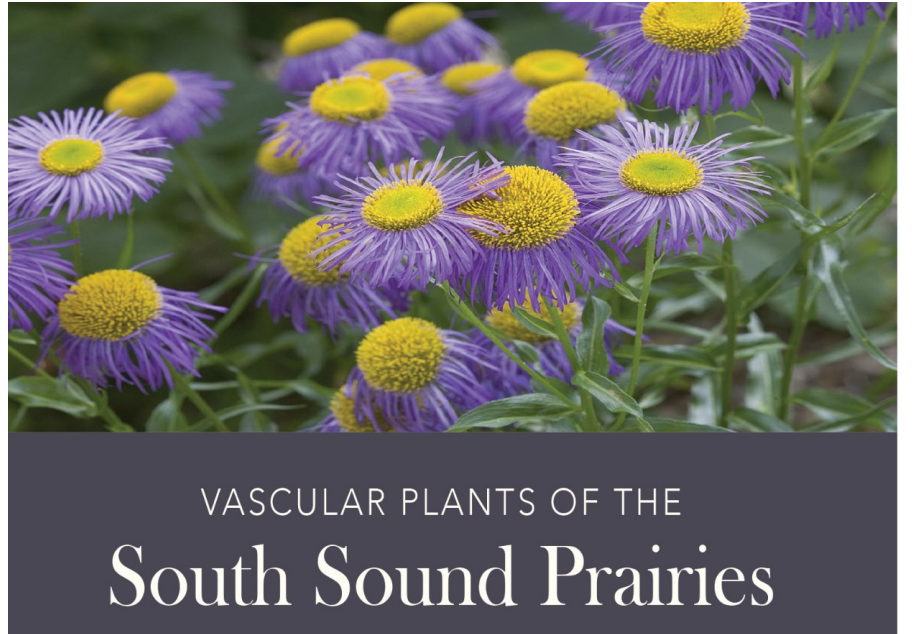

\section{EDITED BY FREDERICA BOWCUTT AND SARAH HAMMAN}

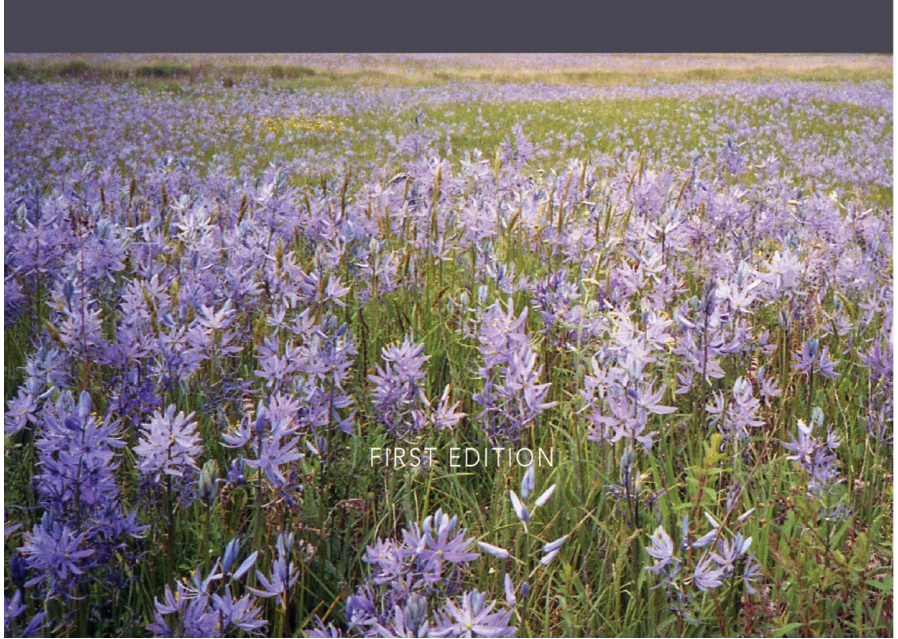

Violaceae-Violet Family

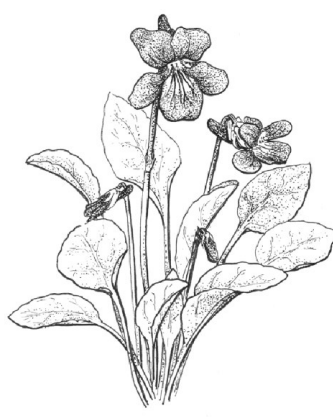

Viola adunca ssp. adunca early blue violet

A native herbaceous perennial that grows up to $10 \mathrm{~cm}$ tall, early blue violet has ovate to cordate leaves. The blue to deep violet flowers are 5-petaled and sepaled and zygomorphic (irregular in symmetry). It thrives in disturbed areas, moist grasslands, meadows, and open forests at low to timberline elevations, blooming from April to August. $V$. adunca can be distinguished from the similar, low-elevation species, $V$. howellii by its long, narrow spurs and nonciliate sepals. V. howellii has broad spurs and ciliate sepals.

\section{Viola glabella} stream violet

Stream violet is a native perennial herb with entire, serrate, heart-shaped leaves with defined points at the tips. The flower stems reach 5 to $30 \mathrm{~cm}$ tall with no leaves on the lower two-thirds. They are yellow, 5-petaled and sepaled, complete, and zygomorphic. The lower 3 petals have purple penciling. It prefers moist areas, hence its common name. It blooms from March to July.

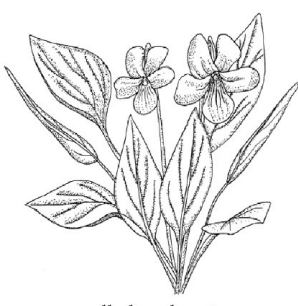

Viola praemorsa var. praemorsa [ . nuttallii var. p. J, upland yellow violet This perennial native violet blooms from April to July and is found primarily on prairies in Thurston County. Yellow flowers are 5-petaled and 5-sepaled, zygomorphic with 2 upper petals and 3 lower petals borne on stems of up to $15 \mathrm{~cm}$. The bottom center petal is penciled with brownish-purple. The reproductive parts are hidden from plain view in a small chamber. Leaves are 3 to $10 \mathrm{~cm}$ long with 5 to $15 \mathrm{~cm}$ petioles. Leaf blades are pubescent, entire margined and teardrop shaped. Leaves have indented veins that almost appear parallel but are actually pinnately netted. The whole plant is short and dense, with flower stems originating basally.

Figure 1 Cover of the field guide designed by student Jackie Argueta, upper photo of showy fleabane (Erigeron speciosus) by Rod Gilbert and lower photo of camas prairie by Frederica Bowcutt. On the right, a page with student illustrations of early blue violet (Viola adunca ssp. adunca) by Kate McSorley, stream violet ( $V$. glabella) by Lisa Hintz, and upland yellow violet (V. praemorsa var. praemorsa) by Brita Zeiler.

Trough/Georgia Basin Ecoregion, which extends from the Willamette Valley of western Oregon north to southwestern British Columbia (Hosten et al. 2006; Thorpe and Stanley 2011). The first edition of the field guide involved contributions from over forty students between 2003 and 2016. The end result was a novel, accessible tool for plant identification tailored to these biodiverse ecosystems. The most commonly used field guide for western Washington by Pojar and MacKinnon (2014) focuses primarily on coniferous forests. The primary Pacific Northwest flora, which was recently updated, uses technical language that makes it inaccessible to many people (Hitchcock and Cronquist 2018). The first print run of 300 copies of
Vascular Plants of the South Sound Prairies sold out in less than two weeks indicating pent up demand for a local field guide of this kind.

Undergraduate students at The Evergreen State College conducted most of the field, herbarium, and library research needed to write the field guide. They generated hundreds of botanical illustrations and voucher specimens. Student staff members in the Evergreen Herbarium also digitized and databased the pressed plant specimens to make them accessible online through the Consortium of Pacific Northwest Herbaria. Short essays covering various aspects of these unique ecosystems were generated for the field 
guide by advanced students and professional scientists from Evergreen, Centralia College, and the non-profit organization Center for Natural Lands Management (CNLM).

Discipline-based skill building formed the bedrock of our work. The field guide created opportunities for students to apply what they had learned through lectures, readings, illustration workshops, and plant taxonomy labs. Through the project, students honed their sight recognition skills for plant identification and learned to use technical dichotomous keys as well as online identification tools. They learned how to portray important diagnostic characters through their detailed scientific illustrations and written descriptions. Building on their increasing competency in plant taxonomy and botanical illustration, students considered the historical ecology of the prairies as anthropogenic ecosystems managed by Indigenous peoples who traditionally used fire to promote a polyculture of native food, fiber, forage, and medicine plants (Leopold and Boyd 1999; Norton 1979; Sinclair et al.
2006; Storm and Shebitz 2006). Readings and lectures also examined the impacts of European and EuroAmerican (white) settlement of western Washington during the nineteenth and early twentieth centuries as it relates to historical and contemporary conservation issues (Hintz 2016a).

\section{Floristic Research Projects and Their Importance to Conservation Work}

Herbarium "specimens are the fundamental records of [plant] biodiversity" in large part because they enable other researchers to verify identifications if there is a question (Prather et al. 2004:216). In the Western botany tradition, collections of pressed, dried, and mounted plant specimens are housed in herbaria typically on college and university campuses. State parks, the United States Forest Service, National Park Service, and other land managing governmental agencies rarely have the resources to fund years of floristic research or maintain collections of voucher specimens. Yet floristic information and herbarium specimens are critical to science-based land management. For this reason, it can be argued that

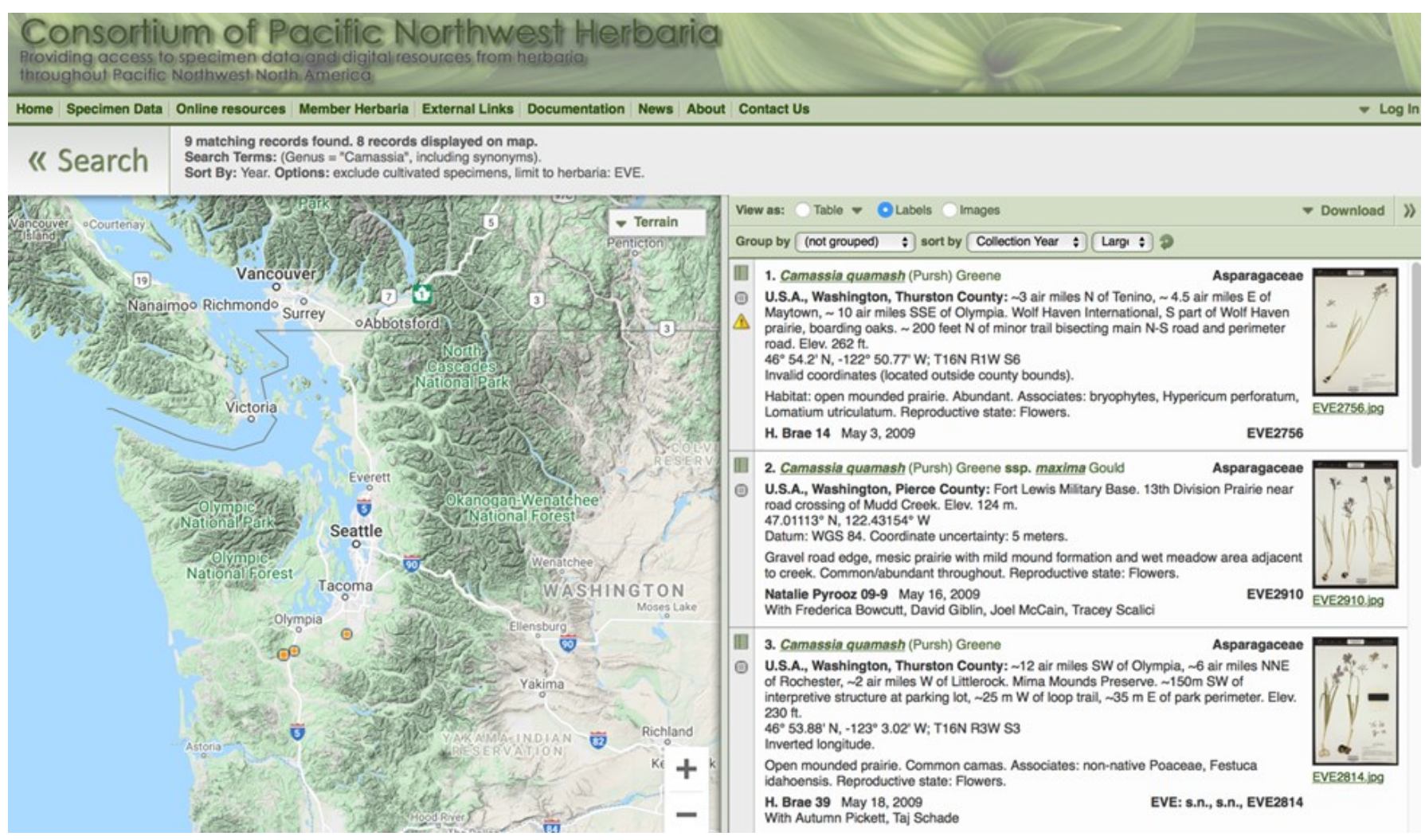

Figure 2 High-resolution images of herbarium specimens of prairie and oak woodland plants housed in the Evergreen Herbarium (EVE) can be accessed on the Consortium of Pacific Northwest Herbaria website at https://www.pnwherbaria.org. The Salish Sea is pictured on the upper left and camas specimens on the far right. 


\title{
Welcome to the Salish Sea Prairie Flora Project
}

\begin{abstract}
This website is part of the ongoing effort at The Evergreen State College to document the flora of the prairies of south Puget Sound (aka Salish Sea). Evergreen students and local experts in prairie ecology have joined forces to create the first edition of the Vascular Plants of the South Sound Prairies. This book aids in the identification of prairie plants and serves as a resource for information about the natural and human history of south Salish Sea prairies. A second edition is currently in progress to expand the number of species covered to over 200 plants. Scroll down to the Thumbnail gallery to find information about particular prairie and oak woodland plants.

The thumbnail pictures are credited in each monograph. Please click through to find each photographer's name, and thank you to the photographers who have been so generous with the usage of their beautiful photos. If you have any questions or concerns, please email bowcuttf(at)evergreen(dot)edu
\end{abstract}

\section{Thumbnail gallery}

Prairie Plant Profiles sorted by scientific name. Click on the plant name you are interested in to view it's profile.

A

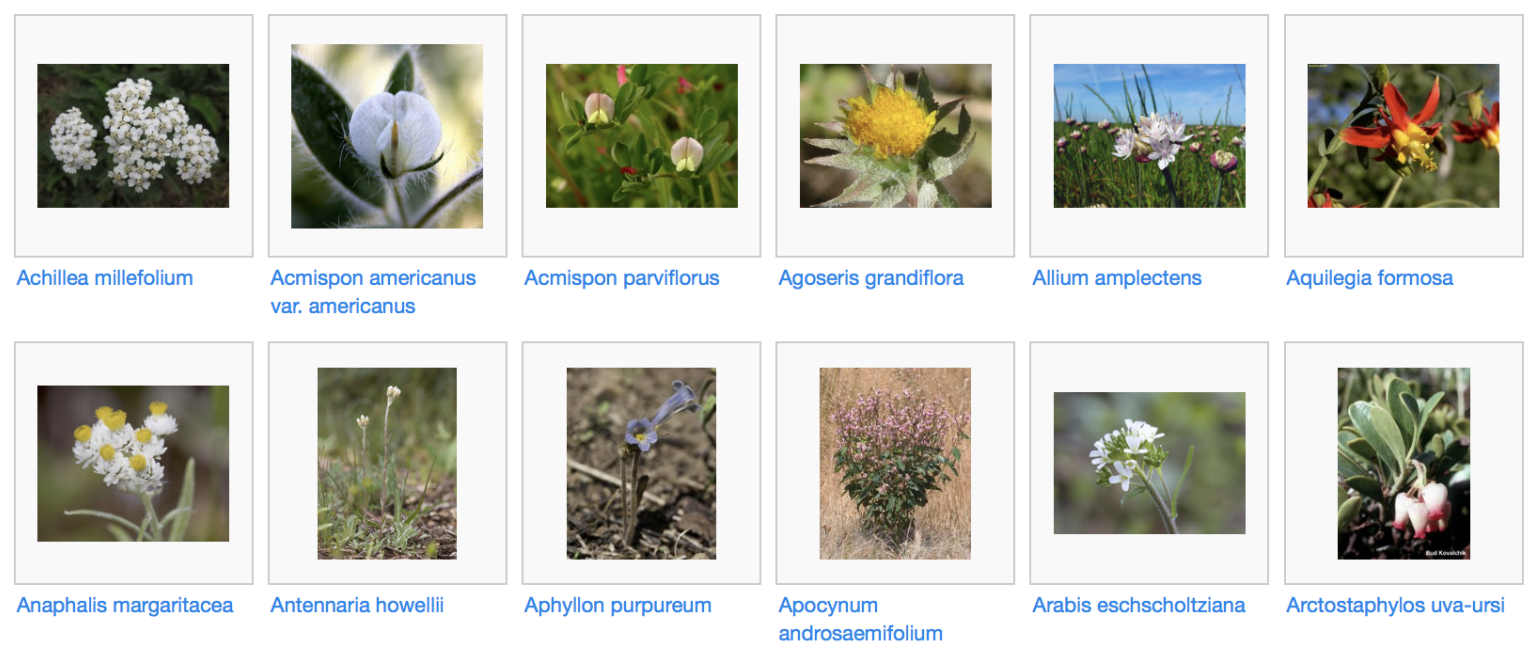

Figure 3 Salish Sea Prairie Flora Project wiki generated by undergraduate students. For photo credits and additional information, go to wikis.evergreen.edu/pugetprairieplants.

institutions of higher learning have the potential to play vital roles in floristic research.

Although the Evergreen Herbarium is a small one, our students contribute to one of the most urgent conservation concerns in our immediate area through our ongoing multi-year commitment to documenting the floristic diversity of local camas prairies and associated oak woodlands. In the words of University of Washington prairie expert Peter Dunwiddie (Bowcutt and Hamman 2016:back cover):

This project represents an important contribution towards furthering public understanding of, and support for, a rare ecosystem. By developing an illustrated flora for the prairie habitats in this region, this effort will significantly increase public awareness of the unusual species that are found in this highly endangered habitat. ... Furthermore, this effort is being carried out in a manner that greatly facilitates participation by students in the preparation of the text and figures. This is a commendable and creative effort to engage nonprofessionals in furthering the conservation of this habitat, while educating themselves and others in the process.

Biodiversity informatics make it possible for us to share our research results broadly through the internet to facilitate collaboration with other public institutions, non-profit organizations, and local tribes. Images of our prairie voucher specimens are available on a website maintained by the Consortium of Pacific Northwest Herbaria (Figure 2). These high-resolution images can be used to confirm plant identifications and locate populations. In addition to making our voucher specimens available online, undergraduate students created a website featuring Wikipedia-style pages for over 100 vascular plants with descriptions and photographs including images of the magnified 
seeds (Figure 3). These photographs aid in the seed gathering and identification work required for propagating native species for restoration. Information sharing online can amplify the contributions small liberal arts colleges with an herbarium can make to regional conservation.

\section{Interdisciplinary, Place-Based Pedagogy}

Interdisciplinary studies "best prepares students for the complex issues facing our society" (Smith 2003:50 -51; see also Kinzie 2013). Many college students are interested in learning about Indigenous uses of plants for food, fiber, and medicine. However, ahistorical ethnobotanical inquiry has a deeply problematic legacy given the often negative social and environmental consequences of settler colonial commercialization of plants after ethnobotanical information is shared, often without permission. Indeed, botanists have a long history of aiding imperialist and colonial agendas as resource scouts expanding commodity frontiers by seeking out potentially profitable plants and exploiting Indigenous knowledge (Brockway 2002; Schiebinger 2004). Even "well-meaning" researchers can unintentionally cause harm by attempting to "help" Indigenous people through patronizing, self-serving, and/or voyeuristic research (Land 2015; Smith 2012). With this legacy in mind, higher education needs to deliver more than a narrow vocational training.

Although attempting to "decolonize our minds" is an ongoing process, place-based curriculum can help to decenter epistemic imperialism including hegemonic claims of objective, universal scientific knowledge construction (Gahman and Legault 2019:65-66; see also Tuck and Yang 2012). In my field plant taxonomy program, we visited many remnant and restored prairies on the ancestral lands of Coast Salish peoples, including the Chehalis and Nisqually Nations. These cultural landscapes or ecosystems are among Washington's most endangered habitats and the fraction of them that remain are significantly degraded. Due to the loss in acreage of roughly $97 \%$ of these special ecosystems since white settlement began in the mid-1800s, a number of species that depend on them are listed under the Endangered Species Act (Hintz 2016b). Ecological restoration is funded in part to prevent the extinction of prairie-dependent species, such as the federallyprotected golden paintbrush (Castilleja levisecta). The technical expertise of how to foster prairie and oak woodlands in conifer-dominated western Washington has grown significantly over the last few decades, including the use of fire (Dunwiddie and Bakker 2011; Hamman et al. 2011). There is also a growing awareness that recognizing and honoring traditional ecological knowledge is critical "if restoration is to accurately reflect the historical ecology and ethnoecology of place" (Storm and Shebitz 2006:266).

Currently, tribal involvement in prairie restoration in the south Salish Sea region is very limited. However, efforts are underway to cultivate "partnerships based in trust, reciprocity, and respect" that "[draw] on western and Indigenous ways of knowing" to foster healthy prairie ecosystems (Nabhan 2018:84). Prescribed burning has already been adopted as a common management tool, vindicating Indigenous stewardship practices developed over thousands of years. Unfortunately, contemporary burning promotes some non-native plants, such as hairy cat's-ear (Hypochaeris radicata) and various perennial pasture grasses, spurring some restoration ecologists to use herbicides to control these invasive species to favor native species. However, tribal members from the area express concern about the safety of harvesting plant foods, medicines, and basket weaving materials after pesticide spraying. The complex subject of non-native plants in the context of conservation offers a rich topic for student discussion. White settlers introduced Eurasian pasture grasses because they withstood continuous livestock grazing, particularly sheep, better than the native bunchgrasses and they made better hay (Brockway 2002:45; Norton 1979:179). Gardening served as a central metaphor for colonists who sought to subdue and civilize unruly native landscapes in part through "displanting" the Indigenous species deemed inferior (Mastnak et al. 2014).

\section{Decolonizing Botanical Knowledge}

Decolonization of knowledge (or epistemological decolonization) efforts often incorporate deconstruction and reconstruction. According to Madden and McGregor (2013:372),

deconstruction involves examining colonization and colonial strategies that continue to be utilized by settlers to exploit, and justify the theft of, Indigenous lands and resources … Reconstruction centers Indigenous epistemologies and ontologies in working toward localized education and research priorities as outlined by Indigenous communities. 
As I wrestle with the question what might it mean to decolonize botanical knowledge, my current pedagogical praxis includes: (1) helping students understand the historical roots of Western botany as a discipline including its role in biopiracy, linguistic imperialism, and intellectual property rights violations (Bowcutt and Caulkins 2020; Brockway 2002; Schiebinger 2004); (2) making land dispossession, genocide, resistance, and survival visible in historical accounts of Indigenous peoples in part through placebased education; (3) bringing my students into dialogue with contemporary Indigenous scholars; and (4) drawing from multiple disciplines to teach students analytical tools that are useful for a more nuanced ability to interpret and link historical and ecological information.

In Decolonizing Methodologies, Linda Tuhiwai Smith (Ngāti Awa and Ngāti Porou, Māori) addresses the importance of deconstructing imperial accounts of the past, which students practiced in this project through their study of white settlement's ecological impacts on local prairies. During white settlement of western North America, Euro-Americans actively stopped the burning practices of Native peoples (Anderson 2005; Bowcutt 2015; Bunting 1997; Leopold and Boyd 1999; Norton 1979). Most settlers failed to recognize or respect the traditional ecological knowledge of Indigenous peoples who used fire as a tool to clear competing conifers and favor prairies and oak woodlands (Stewart 2002; Whitlock and Knox 2002). These cultural ecosystems maintained by regular burning support valued plant foods including acorns from Oregon white oak trees (Q. garryana), camas bulbs (Camassia spp.), berries (Amelanchier alnifolia, Fragaria spp., and Rubus ursinus), biscuitroot (Lomatium spp.), bracken fern rhizomes (Pteridium aquilinum), riceroot (Fritillaria affinis) and wild sunflower seeds from deltoid balsamroot (Balsamorbiza deltoidea) as well as medicine and basket plants such as nettle (Urtica dioica) and hemp dogbane (Apocynum cannabinum) (Carpenter 1986:8; Norton 1979). Prairie-oak woodland mosaics also provide important forage for deer (Odocoileus hemionus columbianus) and elk (Cervus canadensis ssp. roosevelti) (Norton 1979; Weiser and Lepofsky 2009:185). After the Nisqually Nation and other local tribes obtained horses through trading with the Nez Perce Tribe, the prairies provided pasturage as well (Norton 1979). Instead of recognizing the existence of different forms of knowledge and legitimate land management goals, fire was seen as a threat to personal property by settlers.
Native people who persisted in trying to use it as a tool on a landscape-scale were viewed as arsonists who wasted natural resources.

Through deconstructed accounts of the past, students learned how racial hierarchies promoted as objective scientific fact by nineteenth and early twentieth century anthropologists among others served to justify colonization. Despite their active use of fire to promote desirable plants for food, fiber, forage, and medicine production, Indigenous peoples were dispossessed of their lands during white settlement in part based on the argument that only active agricultural land use gave people legitimate land claims. As ethnobotanists Douglas Deur and Nancy J. Turner (2005:8) argue, "misrepresentation of subsistence practices by explorers, settlers, and early anthropologists" led to the misperception that Northwest Coast Indigenous peoples did not cultivate plants for food but rather passively gathered food stuffs. American land claims in the nineteenth century hinged on a definition of agriculture that excluded the Coast Salish food production systems.

By learning about the collision of worldviews that occurred during British settlement and subsequent American expansion, students began to understand the impacts of white settlement on local ecosystems and Indigenous communities. Students considered how early agriculture during white settlement damaged cultural landscapes that local tribes depended on, including the Nisqually and Puyallup Indian Tribes. In 1838, Hudson's Bay Company employees based in London decided to establish an agricultural outpost near the mouth of the Nisqually River (Carpenter 1986). To distinguish it from the fur trade branch of the business, it was called the Puget Sound Agricultural Company. Once in operation, it introduced thousands of Spanish horned cattle, horses, sheep, and other livestock that significantly damaged native food plants like camas growing in the area (Norton 1979). The British company was shipping "surplus grain, butter, and cheese to the Russians in Alaska" by 1841 and in 1845, they exported 10,000 pounds of wool to England (Washington State Archives 2020). Through floristic analysis and lidar aerial photography, students learned to interpret the visible impacts of this history on the land in the form of prairies degraded by plowing, overgrazing, and introduction of non-native plants.

Using a reconstructionist lens, students engaged with the work of various contemporary Indigenous 
scholars to center Indigenous ways of knowing. Students considered the responsibility of humans to relate to other life forms as relatives, an aspect of kincentric ecology. Enrique Salmón (2012:21) explains in his book Eating the Landscape: "without human recognition of their role in the complexities of life in a place, the life suffers and loses its sustainability." Through a TEDx talk on food sovereignty, local nutrition educator Valerie Segrest (Muckleshoot) introduced students to the concept of traditional native foods being critical for contemporary Indigenous health. Students also read the work of fire ecologist Frank Lake (Karuk) and restoration ecologist Dennis Martinez (O'odham/Chicano) who explained the opportunities and challenges of integrating traditional ecological knowledge into ecological restoration projects (Senos et al. 2006). Linguistic scholar Zalmai Zahir (Sioux) introduced students to Lushootseed names for common native plants and the etymology of these Indigenous names. Lushootseed is one of the Coast Salish languages currently undergoing active revival. The work of two contemporary Indigenous artists Matika Wilbur (Swinomish/Tulalip) and Evergreen alumna Tracy Rector (Choctaw/Seminole) illustrated the concept of survivance for students. The term celebrates survival and resistance; it "accentuates the degree to which Indigenous peoples and communities have retained cultural and spiritual values and authenticity in resisting colonialism" (Smith 2012:146). Rector's multimedia installation 'Clearwater: People of the Salish Sea' (2018) shown in the 'Double Exposure' exhibit at Seattle Art Museum featured current-day camas harvesting.

Through discussions and assignments, students worked to synthesize what they learned from Indigenous scholars with their other studies on the historical ecology and ecological restoration of local prairies and oak woodlands. Although it does not address the root causes of harm caused by colonialism, incorporating Indigenous content and place-based histories of colonization into botany curriculum can be viewed as "short-term, harm reduction practices" that "can become the first step toward opening up other, more thoroughly transformative higher education futures" (Stein 2019:157).

\section{Capstone Opportunities}

Offering capstone opportunities for undergraduate students who are ready for advanced research is widely recognized as a high-impact practice (Kuh 2008). The integrative learning that often occurs through these culminating experiences can result in more holistic understanding for students (Kinzie 2013). In the context of this project, nearly twenty students have gained capstone experiences typically in their junior or senior year through an internship, a paid fellowship, and/or independent study. In 2016, I launched the Prairie Conservation Internship program with Sarah Hamman, a restoration ecologist for a local non-profit conservation organization and a frequent visiting faculty member in the Master in Environmen-

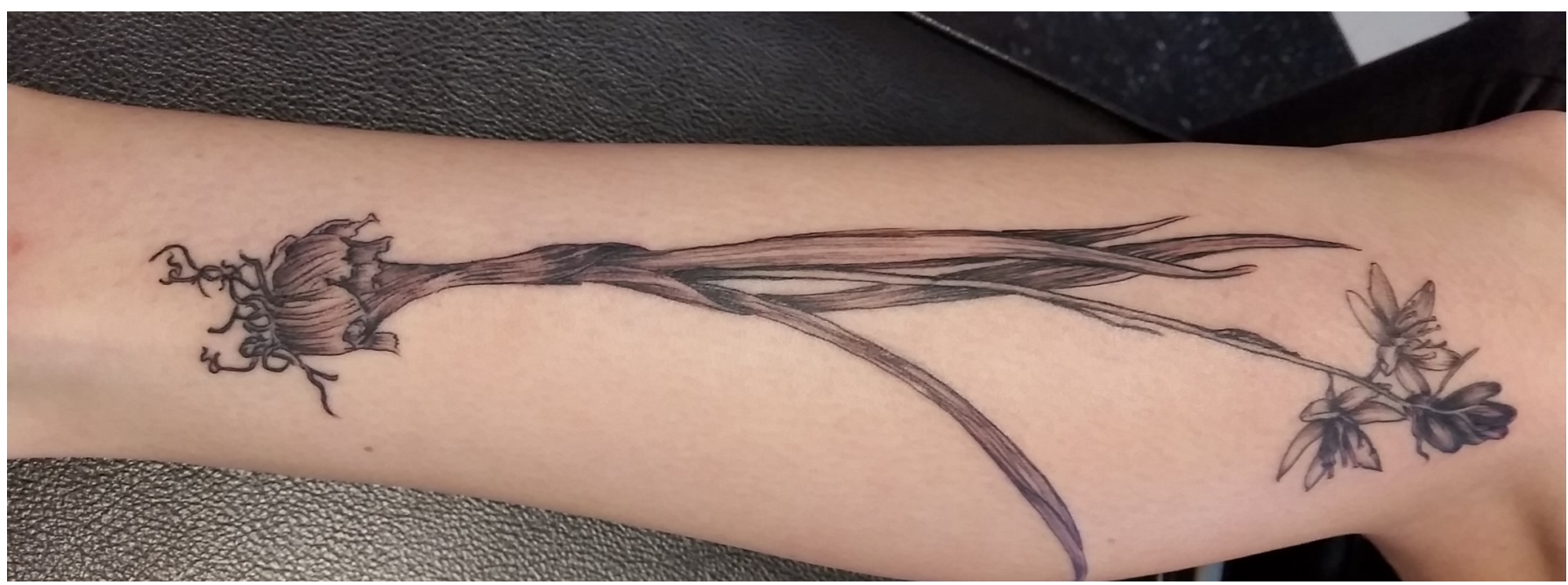

Figure 4 Nisqually Tribal member Chantay Anderson's graduation present to herself, a camas tattoo based on an illustration by Frederica Bowcutt from the field guide. Photo and tattoo by Sean Lindseth, published with permission from Chantay Anderson. 
tal Studies program at Evergreen. Formerly she worked for CNLM, but recently joined the Ecostudies Institute. With the support of Dr. Hamman as their field supervisor, the interns gain hands-on experience in prairie restoration and ecological monitoring techniques in a professional setting. After graduation, many of the interns have successfully competed for paid positions in prairie restoration with CNLM and AmeriCorps. One former intern, Chantay Anderson, now works for the Nisqually Tribe on food sovereignty initiatives as a tribal member and as the Nisqually Community Garden Project Supervisor (Figure 4). The praxis of decolonizing education is always a work in progress. Having Native students complete the program creates the potential for building ongoing relationships that can facilitate greater collaboration with local tribal communities in the future.

Multiple students have completed capstone experiences in support of this collaborative floristic research project. Two students in their senior year served as paid Summer Undergraduate Research Fellows (SURF). Tari Gunstone in 2018 and Geena Barker in 2019 contributed towards a second edition of the field guide. Adrienne Chitwood, who aspires to become a scientific illustrator, completed six-months of independent work during her senior year to generate thirty-five new illustrations. Lisa Hintz learned to use an auto-montage microscope and then generated high-resolution photographs of seeds from native plants used in local prairie restoration most of which are not available commercially. Her images continue to be used by The Friends of Puget Prairies to sort hand-gathered seeds and weed out non-native species. Various non-profit organizations propagate plants for restoration efforts from the sorted seeds. For her final senior project, Hintz wrote a history of the impact of white settlement on local prairie ecosystems drawing from primary historical materials. Although she graduated in 2017, Hintz remains committed to the project and will be one of the editors of the second edition which is slated for publication in 2023.

\section{Applications to Other Institutions of Higher Learning \\ Many opportunities to contribute to plant conservation exist in the United States that could become a focus of project-based learning. Even at more traditional universities and colleges, similar projects could be developed as a capstone experience}

for seniors or a summer immersive practicum for upper division students. Many students engaged in botany and environmental studies curriculum are doing so with the hopes of contributing in meaningful ways that advance environmental sustainability and social equity. The incorporation of bioinformatics into floristic research has the potential to improve access to herbaria in ways that help diversify its users and contributors. Most major herbaria at institutions of higher learning in the United States are already digitizing their collections. However, people of color remain underrepresented in science. Decolonizing pedagogical praxis might begin to address this problem. According to Clare Land (2015:82), author of Decolonizing Solidarity "a key role for non-Indigenous people seeking to be politically supportive of Indigenous people is to educate themselves and other non-Indigenous people, to lessen the demands on Indigenous people to do this educating." Learning historical ecology can be a good place to start.

\section{Conclusion}

Herbarium-based floristic research involving undergraduate students can help to reimagine botany curriculum. Decolonization praxis can begin to relieve the burden often put on Indigenous peoples to educate others about the ecological legacy of colonialism. Through their study of prairie biodiversity enhanced by Indigenous burning practices, students came to appreciate how restoration of these cultural landscapes requires an interdisciplinary approach that is historically grounded and involves tribal partners as well as Indigenous leadership. Based on this case study, students benefited from a place- and project-based curriculum that engaged them "in an active quest for understanding in a faculty-student cooperative environment" (Noam Chomsky quoted in Freire 2018:194). Students embraced their work, mastered new skills, contributed to collective work, and made valuable contributions to local biodiversity conservation while studying the history of colonialization and its legacy in the context of local prairie and associated oak woodland restoration. By responding to and supporting student interests, experiential learning and purposeful work can result in good outcomes for both students and the conservation efforts they serve.

\section{Notes}

${ }^{1}$ According to cultural anthropologist Joyce LeCompte, some people prefer the term cultural 
ecosystems over cultural landscapes to more clearly distinguish systems that require human involvement to persist (June 2020, pers. comm.).

\section{Acknowledgments}

The Evergreen State College sits on the traditional lands of the Medicine Creek Treaty Tribes: the Squaxin Island Tribe, Nisqually Indian Tribe, and the Puyallup Tribe of Indians. The 1854 treaty ceding these lands remains in dispute. I am grateful to The Evergreen State College, The Evergreen State College Foundation, and the Washington Native Plant Society for generous support of the Salish Sea Prairie Flora project. I received valuable feedback on earlier drafts of this essay from Geena Barker, Sarah Hamman, John McLain, Julia Metzker, Katherine Sackman, Eirik Steinhoff, and two anonymous reviewers. Thanks also to Andrew Flachs, Andrew Gillreath-Brown, and Marc Morris for their skillful editorial work. Sarah Haynor updated the wiki for Figure 3. Thank you to my former students for permission to use their work.

\section{Declarations}

Permissions: I received written permission to use images of and by my former students who are acknowledged in the manuscript.

Sources of funding: I am grateful to The Evergreen State College, The Evergreen State College Foundation, and the Washington Native Plant Society for generous support of the Salish Sea Prairie Flora project.

Conflicts of Interest: None declared.

\section{References Cited}

Anderson, M. K. 2005. Tending the Wild: Native

Knowledge and the Management of California's Natural

Resources. University of California Press, Berkeley, CA.

Bowcutt, F. 2015. The Tanoak Tree: An Environmental History of a Pacific Coast Hardwood. University of Washington Press, Seattle.

Bowcutt, F., and T. Caulkins. 2020. Co-teaching Botany and History: An Interdisciplinary Model for a More Inclusive Curriculum. Isis 111:1-9. DOI:10.1086/711071.

Bowcutt, F., and S. Hamman, eds. 2016. Vascular Plants of the South Sound Prairies. The Evergreen State College Press, Olympia, WA.

Brockway, L. H. 2002. Science and Colonial Expansion: The Role of the British Royal Botanic Gardens. Yale University Press, New Haven, CT.
Bunting, R. 1997. The Pacific Raincoast: Environment and Culture in an American Eden, 1778-1900. University Press of Kansas, Lawrence, KS.

Carpenter, C. S. 1986. Fort Nisqually: A Documented History of Indian and British Interaction. Tahoma Research Service, Tacoma, WA.

Deur, D., and N. J. Turner, eds. 2005. Keeping It Living: Traditions of Plant Use and Cultivation on the Northwest Coast of North America. University of Washington Press, Seattle, WA.

Dunwiddie, P. W., and J. D. Bakker. 2011. The Future of Restoration and Management of Prairie-Oak Ecosystems in the Pacific Northwest. Northwest Science 85:83-92. DOI:10.3955/046.085.0201.

Freire, P. 2018. Pedagogy of the Oppressed, 50th Anniversary Edition. Bloomsbury Academic, New York.

Gahman, L., and G. Legault. 2019. Disrupting the Settler Colonial University: Decolonial Praxis and Place-Based Education in the Okanagan Valley (British Columbia). Capitalism Nature Socialism 30:50 -69. DOI:10.1080/10455752.2017.1368680.

Hamman, S. T., P.W. Dunwiddie, J. L. Nuckols, and M. McKinley. 2011. Fire as a Restoration Tool in Pacific Northwest Prairies and Oak Woodlands: Challenges, Successes, and Future Directions. Northwest Science 85:317-328. DOI:10.3955/046.085.0218.

Hintz, L. 2016a. History of White Settlement. In Vascular Plants of the South Sound Prairies, edited by F. Bowcutt and S. Hamman, pp. 43-56. The Evergreen State College Press, Olympia, WA.

Hintz, L. 2016b. Sensitive Species. In V ascular Plants of the South Sound Prairies, edited by F. Bowcutt and S. Hamman, pp. 27-36. The Evergreen State College Press, Olympia, WA.

Hitchcock, C. L., and A. Cronquist. 2018. Flora of the Pacific Northwest: An Illustrated Manual, 2nd Edition. University of Washington Press, Seattle, WA.

Hosten, P. E., O. E. Hickman, F. K. Lake, F. A. Lang, and D. Vesley. 2006. Oak Woodlands and Savannas. In Restoring the Pacific Northwest: The Art and Science of Ecological Restoration in Cascadia, edited by D. Apostol and M. Sinclair, pp. 63-96. Island Press, Washington, DC.

Kinzie, J. 2013. Taking Stock of Capstones and Integrative Learning. Peer Review 15:27-30.

Kuh, G. D. 2008. High-Impact Educational Practices: A Brief Overview. Association of American 
Colleges and Universities [web page]. Available at: https://www.aacu.org/node/4084. Accessed on June 10, 2020.

Land, C. 2015. Decolonizing Solidarity: Dilemmas and Directions for Supporters of Indigenous Struggles. Zed Books, London.

Leopold, E. B., and R. Boyd. 1999. An Ecological History of Old Prairie Areas in Southwestern Washington. In Indians, Fire, and the Land in the Pacific Northwest, edited by R. T. Boyd, pp. 139-163. Oregon State University Press, Corvallis, OR.

Madden, B., and H. E. McGregor. 2013. Ex(er)cising Student Voice in Pedagogy for Decolonizing: Exploring Complexities Through Duoethnography. The Review of Education, Pedagogy, and Cultural Studies 35:371-339. DOI:10.1080/10714413.2013.842866.

Markham, T., J. Larmer, and J. Ravitz. 2003. Project Based Learning Handbook: A Guide to Standards-focused Project Based Learning, $2^{\text {nd }}$ edition. Buck Institute for Education, Novato, CA.

Mastnak, T., J. Elyachar, and T. Boellstorff. 2014. Botanical Decolonization: Rethinking Native Plants. Environment and Planning D: Society and Space 32:363380. DOI:10.1068/d13006p.

Nabhan, G. P. 2018. Food from the Radical Center: Healing our Land and Communities. Island Press, Washington, DC.

Norton, H. 1979. The Association between Anthropogenic Prairies and Important Food Plants in Western Washington. Northwest Anthropological Research Notes 13:175-200.

Pojar, J., and A. MacKinnon. 2014. Plants of the Pacific Northwest Coast, Revised Edition. Lone Pine, Auburn, WA.

Prather, L. A., O. Alvarez-Fuentes, M. H. Mayfield, and C. J. Ferguson. 2004. Implications of the Decline in Plant Collecting for Systematics and Floristic Research. Systematic Botany 29:216-220. DOI:10.1600/036364404772974347.

Rector, T. 2018. Clearwater: People of the Salish Sea. [Multimedia installation]. In Double Exposure [Exhibition]. Seattle Art Museum, Seattle, WA. June 14 - September 9.

Salmón, E. 2012. Eating the Landscape: American Indian Stories of Food, Identity, and Resilience. The University of Arizona Press, Tucson, AZ.
Schiebinger, L. 2004. Plants and Empire: Colonial Bioprospecting in the Atlantic World. Harvard University Press, Cambridge, MA.

Segrest, V. 2014. Food Sovereignty: at TEDxRainier [web page]. Available at: https:// www.youtube.com/watch?v $=$ RGkWI7c74oo.

Accessed on January 6, 2021.

Senos, R., F. K. Lake, N. Turner, and D. Martinez. 2006. Traditional Ecological Knowledge and Restoration Practice. In Restoring the Pacific Northwest: The Art and Science of Ecological Restoration in Cascadia, edited by D. Apostol and M. Sinclair, pp. 393-426. Island Press, Washington, DC.

Sinclair, M., E. Alverson, P. Dunn, P. Dunwiddie, and E. Gray. 2006. Bunchgrass Prairies. In Restoring the Pacific Northwest: The Art and Science of Ecological Restoration in Cascadia, edited by D. Apostol and M. Sinclair, pp. 29-62. Island Press, Washington, DC.

Smith, B. L. 2003. The Evergreen State College: Creating an Institutional Context for Learning Communities. In Learning Communities in Liberal Arts Colleges. National Learning Communities Project Monograph Series, edited by K. Spears and J. D. Arnold, pp. 50-51. The Evergreen State College, Washington Center for Improving the Quality of Undergraduate Education, in cooperation with the American Association for Higher Education, Olympia, WA.

Smith, L. T. 2012. Decolonizing Methodologies: Research and Indigenous Peoples, Second Edition. Zed Books, London.

Stein, S. 2019. Beyond Higher Education as We Know it: Gesturing Towards Decolonial Horizons of Possibility. Studies in Philosophy and Education 38:143-161. DOI:10.1007/s11217-018-9622-7.

Stewart, O. C. 2002. Forgotten Fires: Native Americans and the Transient Wilderness. University of Oklahoma Press, Norman, OK.

Storm, L., and D. Shebitz. 2006. Evaluating the Purpose, Extent, and Ecological Restoration Applications of Indigenous Burning Practices in Southwestern Washington. Ecological Restoration 24:256-268.

Thorpe, A. S., and A. G. Stanley. 2011. Determining Appropriate Goals for Restoration of Imperiled Communities and Species. Journal of Applied Ecology 48:275-279. DOI:10.1111/j. 1365-2664.2011.01972. 
Tuck, E., and K. W. Yang. 2012. Decolonization is Not a Metaphor. Decolonization: Indigeneity Education \& Society 1:1-40.
Washington State Archives. 2020. Territorial Timeline: Puget Sound Agricultural Company Organized [web page]. Available at: https:// www.sos.wa.gov/legacy/timeline/detail.aspx?

id $=178$. Accessed on January 6, 2021. 